\title{
Green Purchase Behavior: the Predictive Roles of Consumer Self- Determination, Perceived Customer Effectiveness and Perceived Price.
}

\author{
${ }^{1}$ Fortune Edem Amenuvor, ${ }^{2}$ Kwasi Owusu-Antwi, ${ }^{3}$ Bae, Seong-Chan Ph.D, ${ }^{4}$ Sean Kwan Soo Shin \\ Ph.D., ${ }^{5}$ Richard Basilisco Ph.D. \\ ${ }^{1} \mathrm{PhD}$ Candidate \\ Department of Business Administration Keimyung University South Korea \\ ${ }^{2}$ Lecturer \\ Department of Marketing Methodist University College Ghana Ghana \\ ${ }^{3}$ Department of Social Welfare Hanil University and Presbyterian Theological Seminary South Korea \\ ${ }^{4}$ Dean of Global Education Institute Namseoul University South Korea \\ ${ }^{5}$ Department of Global Entrepreneurship Hanil University and Presbyterian Theological Seminary South Korea
}

\begin{abstract}
The overarching aim of this research is to empirically test the effect of customers' self-determined needs on perceived customer effectiveness and green purchase behavior while assessing the moderating role of price. To achieve this aim, data is collected from 453 consumers in South Korea. The various hypotheses developed to achieve this aim are tested via the structural equations modeling technique. The results of the study reveal that autonomy, competence, and relatedness positively and significantly affect perceived customer effectiveness. Additionally, autonomy and competence positively and significantly influence green purchase behavior. The study further finds that relatedness is negative but significantly related to green purchase behavior. Moreover, the study reveals that perceived customer effectiveness is positive and significantly related to green purchase behavior. Similarly, the study finds support for the moderating effect of price on the relationship between perceived customer effectiveness and green purchase behavior. The current study provides managerial and theoretical insights into understanding green purchase behavior, self-determined needs as well as perceived customer effectiveness.
\end{abstract}

Keywords: Green Purchase Behavior, Self-Determination, Perceived Customer Effectiveness

\section{Introduction}

The issue of environmental degradation has become a pressing global problem. The United Nations Environment Programme reports that the risks and impacts associated with climate change will significantly increase over the next decade (UNEP, 2016). Accordingly, the annual climate change adaptation costs are estimated to reach US $\$ 300$ billion by 2050 (UNEP, 2015). There is increasing awareness that majority of the environmental problems coupled with their adverse impacts are engendered by human activities. Chiefly, consumer behavior imposes a twofold environmental burden on the ecosystem through both pollution and the destruction of non-renewable natural resources (Abeliotis et al., 2010). Consequently, inspiring more pro-environmental behavior is a sine qua non for environmental sustainability. This is a problem that businesses, governments, and socio-environmental organizations have consistently sought to address.

Governmental agencies at global, national and local levels have deployed and implemented an extensive range of environment-related regulations, legislations and public policy measures (McDonagh \& Prothero, 2014). Similarly, pressure groups and environmental organizations have created environmental programs and campaigns to sensitize the society about the environment and sustainability issues like unsustainable business practices and environmental degradation (Barbarossa \& De Pelsmacker, 2016). These interventions are re-echoed by firms and industries that have shown a keen interest in green marketing and environmental 
social responsibility (Polonsky, 2011; Romani et al., 2016). In spite of the foregoing efforts, consumers seem apathetic towards engaging in environmentally sustainable behavior, especially green purchase behavior (Olson, 2013). Marketers, policymakers and researchers have made a clarion call for a better comprehension of the factors that promote or inhibit such behavior (Prothero et al., 2011; Barbarossa \& De Pelsmacker, 2016).

Prior research on the drivers of pro-environmental behavior has examined a plethora of factors (Nguyen et al., 2017). These studies have spanned personal levels of demographic and psychological constructs, to external levels of social factors, situational factors and cultural values (Liobikiene \& Bernatoniene, 2017; Leonidoy et al., 2010; Steg et al., 2014). Nonetheless, the factors that affect environmentally sustainable behavior and green purchase lack full comprehension (Tilikidou \& Delistavrou, 2014), especially in the face of evolving characteristics of green consumers (Kumar \& Polonsky, 2017). In spite of the burgeoning state of research on green purchase behavior, some key deficiencies exist in the extant literature. First, previous research has studied how customer factors have been linked to green purchasing ( $\mathrm{Ng} \mathrm{\&} \mathrm{Paladino,} \mathrm{2012;}$ Noor \& Muhammad, 2012; Shahnaei, 2012). Yet, majority of these researches have either focused on environmental concern, social influence and self-image (Lauin \& Ching, 2014); Man-nature orientation (Rehman \& Dost, 2013); environmental consciousness (Ting, Hsieh, Chang, \& Chen, 2019); attitude, perceived controllability and normative influence (Hsu, 2015), among others. Limited attention has been devoted towards assessing how customers' self-determined needs (specifically autonomy, competence, and relatedness) engender green purchase behavior. Secondly, there seems to be paucity of research that employs the self-determination theory in evaluating green purchase behavior. Specifically, majority of the extant research in green purchasing has adopted the theory of planned behavior and its attendant constructs as the theoretical lens. Additionally, research that assesses the role played by perceived customer effectiveness in influencing green purchase behavior remains scarce in the current literature. The study operationalizes perceived customer effectiveness as an individual's belief that the efforts of their actions will provoke a difference in attenuating environmental problems (Ellen \& Cobb-Walgren, 1991). Finally, extant research has demonstrated the effect of price in influencing purchase decisions. This study argues that price is an expression of the value of a product and an important factor that affects consumers' purchase behavior. Hence, perceived price is introduced as a moderating variable in the current study.

Consequently, this research sets out to progress knowledge by offering an extended understanding of the effect of consumer self-determined needs on perceived customer effectiveness and green purchase behavior while accounting for the moderating effect of perceived price. Through this paper, the authors make a humble contribution from a South Korean context, to the ongoing discussion on environmental sustainability, sustainability marketing, and green purchase behavior.

\subsection{Theoretical Framework}

\subsection{Self-Determination Theory}

The self-determination theory is adopted as the theoretical lens for this study. The theory assumes that inherent in the nature of humans is the predisposition to be inquisitive about one's environment. These predispositions are premised on an intrinsic motivation which refers to the type of behaviors done in the absence of external impetus, that is inherently intriguing and enjoyable (Ryan \& Deci, 2000). Selfdetermination theory (SDT) has also been operationalized as an approach to human motivation and personality that adopts a traditional approach called metatheory organismic that underscores the importance of human resources for personality development and self-regulated behavior (Deci \& Ryan, 2000). An individual with innate growth tendencies and psychological needs is the basis for integration between selfmotivation and personality which further provokes positive processes. Prior research has identified three main needs, namely, competence needs (Harter, 1978; White, 1963), relatedness needs (Baumeister \& Leary, 1995) and autonomy needs (deCharms, 1968). Similarly, extant research posits that intrinsic motivation is sustained by the satisfaction of the basic psychological needs for autonomy, competence, and relatedness. The need for autonomy refers to the experience of behavior, volitional and reflectively self-endorsed. The need for competence refers to the experience of behavior as effectively enacted, while the need for relatedness refers to feeling connected with significant others, cared for or the fact that one belongs to a given social milieu (Vlachopoulos \& Michailidou, 2006). Ryan and La Guardia (2000) note that relatedness 
implies a desire to have others respond with a level of sensitivity and care to one's experience and convey that one is loved and significant. These needs are crucial for the facilitation of the optimal function of growth and integration and as well, for constructive social development and personal welfare (Ryan \& Deci, 2000). Self-determination theory further highlights the relevance of intrinsic motivation within oneself and the individual freedom to act. The theory stresses the importance of humans' mental resources for selfregulation behavior and personality development. Self-determination has been employed as a framework to study issues such as addiction, weight loss, compliance in treatment and physical activities (Green 2006; Williams et al., 1995). This theory is relevant to this study and is adopted to provide categories for analysis.

\subsection{Literature Review}

\subsubsection{Green Purchase Behavior}

The plethora of environmental issues faced by consumers is the key reason behind the shift from traditional (non-green) purchasing behavior to greener purchasing patterns. Mostafa (2007) conceptualizes green buying behavior as the consumption of environmentally friendly products that are 'sensitive/responsive', 'recyclable/conservable' and 'benevolent/beneficial' to the environment. To this end, Dagher and Itani (2012) argue that consumers are putting in efforts to help improve the environment with green purchasing. Also, being environmentally friendly is not the only objective of consumers who engage in green purchase behavior; they are also impelled to purchase green products when they know that purchasing such a product will bring them immediate benefits (Vermillion \& Peart, 2010). Kotler (2011) contends that consumers are using a new dimension-the degree of social corporate responsibility towards the environment when they are choosing among available brands in the market. The percentage of consumers who had never bought a green product decreased to less than one-half (Manget et al., 2009). Kotler (2011) emphasizes the value of the product market for healthy and sustainable lifestyles by noting that such a market includes energy-efficient products, solar panels, and eco-tourism among other items. Green consumers are reshaping marketplaces in many significant ways (Vermillion \& Peart, 2010), and are recognizing the colossal impact that their buying activities have on the environment (Rahbar \& Abdul Wahid, 2011). This in effect, serves to solidify the position of the environment as a top world concern and brings this study into a proper perspective to empirically examine how consumers' self-determined needs impact green purchase behavior.

\subsubsection{Self-Determined Needs}

The self-determination theory maintains that internalized motivation emanates because humans have innate predispositions to integrate rationales for behavior into their self-identity (Deci \& Ryan, 2000). The theory accentuates the fact that autonomous motivation and choice, rather than controlled motivation and choice, engineer positive behavior change, effective performance as well as psychological wellbeing (Moller et al., 2006). At the heart of the theory of self-determination are three psychological needs constructs and/or variables of motivation (Autonomy, Competence, and Relatedness) (Williams et al., 2007). The next sections throw more light on each of them.

\subsubsection{Autonomy}

From a self-determination theoretical stance, autonomy is operationalized as individuals' need to act with a sense of ownership of their behavior and feel free psychologically (Deci \& Ryan, 2000). According to deCharms (1968), the need for autonomy draws from the notion of locus of causality, being the origin of one's actions rather than being pushed and pulled about by external forces. The need for autonomy was the focus of the early self-determination theory research, as it proved to be instrumental in explaining the negative impact of extrinsic incentives on the emergence and sustainability of intrinsic motivation (Deci, Ryan, \& Koestner, 1999). Deci and Ryan (2000) further note that among the three basic psychological needs, the need for autonomy remains among the most controversial, even though this is primarily due to a misconception of the nature of the need. Specifically, the need for autonomy does not imply a need to act independently from the desires of others; but the need to act with a sense of choice and volition, even if doing so means acceding to the wishes of others (Leuven \& Arkansas, 2016). The other two basic psychological needs compared with autonomy, are less controversial or misconceived.

\subsubsection{Competence}

According to Vallerand and Ratelle (2002), the need for competence signifies a desire by humans to efficiently interact with one's environment to feel competent in achieving desired outcomes. Competence 
transcends beyond self-efficacy, as it is not only a measure of confidence in ability but also embodies a need, of which fulfillment, is a source of satisfaction and a contributor to well-being over and beyond any satisfaction resulting from the outcomes that might be yielded by competence (Deci \& Ryan, 2000). In the context of this research, it can be argued that customers' ability to engage in green purchase behavior is premised on their ability to satisfy their need for competence. The need for competence has further been conceptualized as the need to feel a sense of mastery over the environment and to develop new skills. The need for competence originally became a focus of self-determination research as researchers sought to elucidate how verbal praise could still enhance intrinsic motivation, despite its extrinsic nature (Deci et al., 1999). Currently, the self-determination theory views the need for competence as innate to the natural tendency to explore and manipulate the environment, as well as in the search for optimal challenges.

\subsubsection{Relatedness}

The need for relatedness is the final and the most recent addition to the basic psychological needs. The need for relatedness epitomizes the need to feel connected to at least some others, (to love and care for others and to be loved and cared for by others) (Baumeister \& Leary, 1995). This need is satiated when individuals see themselves as members of a group, experience a sense of communion, and form close relations. The inclusion of relatedness as a basic psychological need was premised in its evolutionary benefits in terms of survival and reproduction. The need for relatedness is sometimes characterized as being less immediately essential for some outcomes than the need for autonomy or competence. For instance, a child may intrinsically enjoy playing with toys alone; meaning the activity itself does not satisfy the need for relatedness. Nevertheless, self-determination theory maintains such intrinsic motivation could not emerge in the absence of secure relational attachments (Broeck \& Rosen, 2016; Deci \& Ryan, 2000).

\subsection{Perceived Customer Effectiveness}

Perceived customer effectiveness is conceptualized as an individual's belief that the efforts of their actions can make a difference in solving environmental problems (Wiener \& Cobb-Walgren, 1991). It refers to a domain-specific belief that an individual's efforts can make a difference in the solution to a problem. Perceived customer effectiveness is related to the concept of perceived behavioral control. The common thread is that individuals' actions and intentions are affected by the extent to which they believe the aversiveness or occurrence of an event can be affected by their actions (Thompson, 1981). Whereas perceived customer effectiveness has been linked to more generic feelings of control (Henion \& Wilson, 1976) of a positive correlation with a locus of control, it is regarded as domain-specific (Allen, 1982) and could be affected directly by direct experience, experiences of others and knowledge. The extent to which people feel that they have little behavioral control over the performance of a behavior has been argued to uniquely reduce behavioral intentions and behavior, even under situations where social norms and attitudes towards the action are favorable (Ajzen \& Madden, 1986; Ajzen, 1985). Similarly, perceived customer effectiveness should affect intentions and behavior if individuals are convinced their behavior will inure to the desired outcome.

\subsection{Perceived Price}

Price has been operationalized in the extant literature as a cost within traditional economics. Nonetheless, prior studies have recognized price as serving to inform people about the value of goods and services (East, 1997). It is one of the non-product attributes of brand associations in which it serves as a crucial association in the creation of brand perceptions, especially concerning value and desirability and serves as a benchmark by which consumers usually segment their knowledge of a category or market (Gummesson, 2008). With the ever-increasing rate of environmental pollution, individuals pay more attention to the environmental situation. More crucially, people pay more attention to healthy and environmentally acceptable lifestyles and increase the purchase of green products. An important factor that affects consumers' choice behavior is product price (Peattie, 2001).

The literature has mostly demonstrated that high prices discourage price-sensitive customers from making purchases. Nevertheless, some consumers construe high prices of green products to mean the products are of high quality and possess trustworthy environmental effects and functions. Most customers are willing to pay a premium to purchase green products. Prior research has found that consumers are willing to pay a 
premium price for green products (Zeithaml, 1998). For instance, in 1989, 67\% of Americans demonstrated the willingness to pay a premium of 5-10\% to buy green products (Laroche et al., 2001). Similarly, in 1991, it was found that consumers with high levels of environmental awareness were alacritous to pay a premium of 15-20\% to purchase green products (Laroche et al., 2001). The literature further underscores that in 1993, $79 \%$ of female British were prepared to pay a certain premium to purchase green products (Biswas \& Roy, 2015). Even so, it has been reported that consumer's inherent willingness to protect the environment far outweighs the importance of price and the latter is not a major factor that influences green purchase behavior (Lin \& Huang, 2015). In effect, the literature has underscored that while high prices may attenuate the motivations of some sections of customers to make purchases, others see is rather as a sign of quality and motivator. Yet still, others disregard price and are influenced by their willingness to protect the environment (which far outweighs price).

\subsection{Hypothesis Development}

\subsection{Self-Determined needs (Autonomy, Competence, Relatedness), Perceived Customer Effectiveness and Green Purchase Behavior}

The basic needs theory (Ryan \& Deci, 2000a) which is a sub theory of the self-determination theory (Deci \& Ryan, 1985, 2000) contends that humans develop and function effectively as a consequence of the social environment and its potential for satisfying basic needs. In the spirit of the self-determination theory (and as has been discussed previously), humans have three basic needs; the innate need for autonomy, competence and for relatedness (Ryan \& Deci, 2000a). The innate need for autonomy is gratified when individuals perceive that they are the origin of their choices and decision and that their actions are in accord with their integrated sense of self. Competence, on the other hand, relates to an individuals' need to feel a sense of mastery through effective interaction within their environment. Relatedness concerns feeling securely attached to and being revered by significant others. Consequently, satisfying these psychological needs is regarded to directly augment an individual's physical and psychological well-being (Deci \& Ryan, 2000). In the pro-environmental literature, perceived customer effectiveness is argued to be a function of how consumers trust their ability and capacity to influence and contribute positively to the environment (Cho et al., 2013). The current study argues that individuals' needs satisfaction will lead to enhancing perceived customer effectiveness. There is very little research that examines how individualistic variables promote perceived customer effectiveness and its interconnect with sustainable consumption behavior. This research further maintains that consumers' perceived effectiveness is enhanced through the satisfaction of autonomy needs, competence needs and relatedness needs. Accordingly, we advance the following set of hypotheses:

H1: There is a positive and significant effect of autonomy on perceived customer effectiveness.

$\mathrm{H} 2$ : There is a positive and significant effect of competence on perceived customer effectiveness.

H3: There is a positive and significant effect of relatedness on perceived customer effectiveness.

Additionally, and following from the preceding discussions, this research argues that consumers' need for autonomy, competence, and relatedness will impel them to engage in green purchase behaviors. All the three self-determined needs (basic psychological needs) are premised on the notion of the locus of causality (being the origin of one's actions, rather than being pulled by external forces) (deCharms, 1968; Harter, 1978; White, 1963; Baumeister \& Leary, 1995; Deci, 1985; deCharms, 1968) and therefore, consumers who are intrinsically motivated through satisfying their needs for autonomy, competence and relatedness will eventually be predisposed towards engaging in green purchases. This sets them apart from other customers whose decision to buy green products are based on external influences. Hence, the following set of hypothesis is proffered:

H4: There is a positive and significant effect of autonomy on green purchase behavior.

H5: There is a positive and significant effect of competence on green purchase behavior.

H6: There is a positive and significant effect of relatedness on green purchase behavior.

\subsection{Perceived Customer Effectiveness and Green Purchase Behavior}

The literature describes perceived customer effectiveness as the ability to affect outcomes and captures the stable beliefs about how consumers' choices are generally effective (Kim \& Choi, 2005; Vermeir \& Verbeke, 2006; Wesley et al., 2012). Perceived customer effectiveness refers to the customer's beliefs that their singular actions make a difference in solving a problem and is evaluated as the self-assessment within the 
context of the issue (Berger \& Corbin, 1992). High perceived customer effectiveness is crucial to prompt customers to channel their positive attitudes into an actual purchase (Ellen et al., 1991). In effect, individuals with positive attitudes towards green consumption are inclined towards supporting green consumption behaviors more, when they are convinced that they can contribute towards solving environmental problems. (Lee, Kim \& Choi, 2014; Cho, Thyroff, Rapert, Park \& Lee, 2013). In the ambit of green consumption, perceived consumer effectiveness is a crucial predictor of green behavioral intentions (Vermeir \& Verbeke, 2008). Specifically, perceived consumer effectiveness is a key prerequisite for predicting consumers' green purchase behavior. Previous research has emphasized that perceived consumer effectiveness can positively influence environmentally responsible behavior. For instance, Berger and Corbin (1992) surmise that perceived consumer effectiveness has a positive effect on environmentally friendly behavior. To this end, this research argues that if consumers believe that their green purchase behavior can generate benefits to the environment, they will increase the purchase of green products. Additionally, since people's behaviors are strongly stimulated by their confidence in their ability to perform, the following hypothesis is submitted.

H7: There is a positive and significant relationship between perceived consumer effectiveness and green purchase behavior.

\subsection{The Moderating Role of Perceived Price}

Product price has been argued to be an important factor in predicting consumers' choice behavior. Arguably, price is considered one of the most dominant factors within the green marketing mix. Most consumers demonstrate high levels of readiness to spend extra price if they perceive that the product they are buying carries extra value. This value is typified in the form of a better taste, an improved performance, a more creative design, an enhanced function or a more attractive visual appeal (Sharma, 2011). Most environmentalists share a common concern of having overpriced green products which are reflected in a higher total environmental cost. Gummesson (2008) notes that price and cost savings are closely tied to any purchasing process and even among environmentally conscious consumers, price is a dominant factor that can make a customer avoid buying a green product (Peattie, 2001). Curiously, price has a key influence on green purchasing.

For instance in Pedro and Lemke's (2013) research, they found that if a product is highly expensive (like cars and washing machines), few consumers pay attention to environmental characteristics if they find themselves impelled to pay premium prices. Interestingly, Pedro and Lamke (2013) further found that consumers who were charged extra for green products spent on products that are categorized in the lowercost category such as recycled paper bags. In effect, consumers are less disposed to purchase green products if they are comparatively costlier than regular products as price affects consumers' green purchase decisions (D’Souza et al., 2006; Blend \& Van Ravenswaay, 1999). Price has consistently been a predictor of green purchasing behavior and prior research demonstrates that this factor affects consumers' green purchasing behaviors. To this end, this study argues that the relationship between perceived customer effectiveness and green purchase behavior will be moderated by perceived price. The theoretical relevance of this argument is premised on the fact that even though consumers' level of perceived consumer effectiveness could lead towards environmentally friendly behavior (like green purchase behavior) as underscored by Berger and Corbin (1992), the perceived price of the green product can actually encourage or discourage the customer from making a purchase. Consequently, the following hypothesis is proposed.

H8: Perceived price moderates the relationship between perceived customer effectiveness and green purchase behavior. 


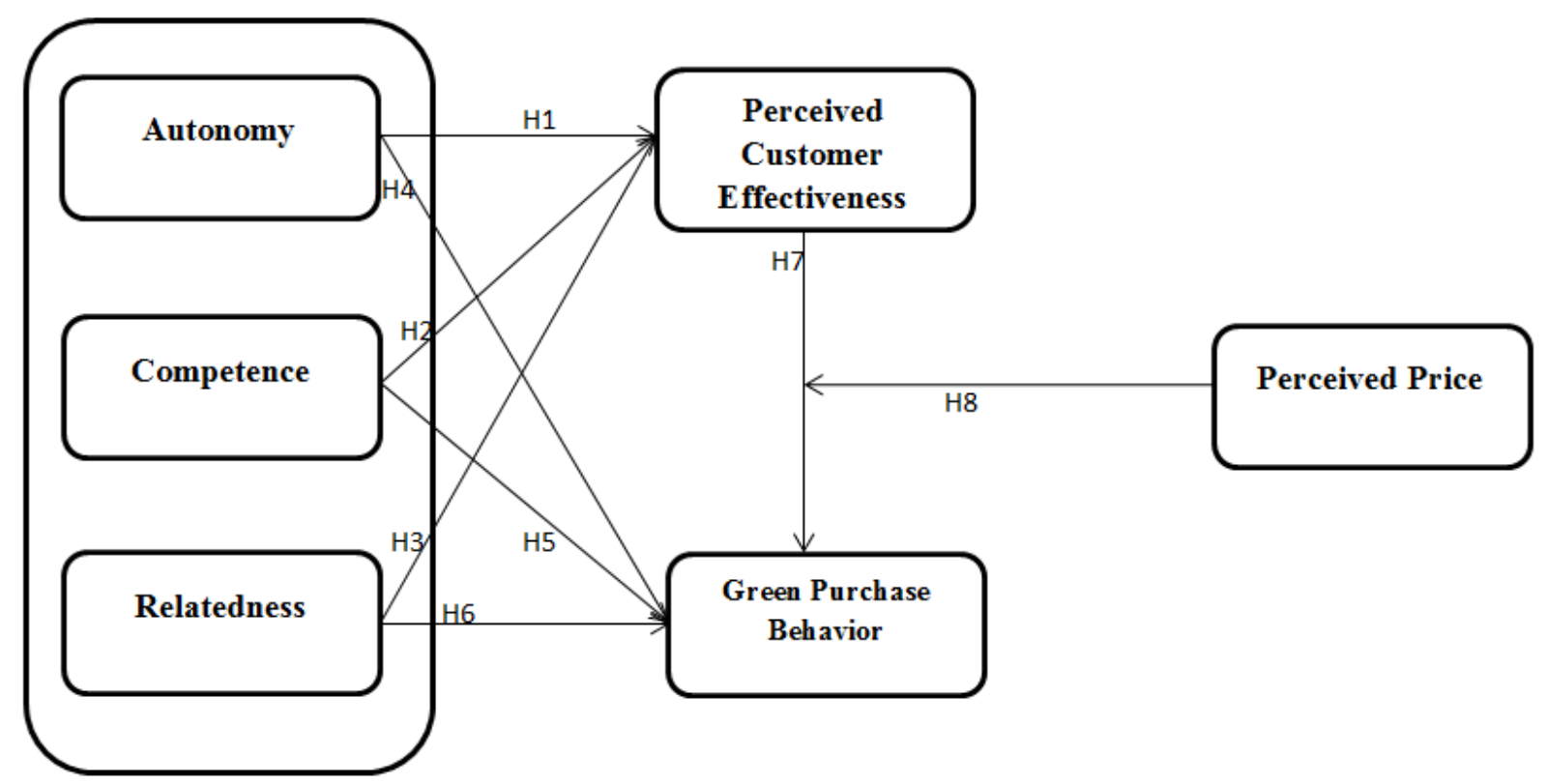

\subsection{Empirical Results}

\subsection{Measurement of Variables}

A quantitative research approach utilizing structured questionnaires was adopted for the current study. This made it possible for the calculations of actual statistical measures of theorized hypotheses on empirical data (Hair et al., 2010). The variables in the questionnaire were made up of measures on autonomy, competence, relatedness, perceived customer effectiveness, green purchase behavior, and perceived price. The statements measuring these variables were evaluated on a five-point Likert scale anchored on " $1=$ strongly disagree" to " $5=$ strongly agree" and " $3=$ neutral". All directional constructs (dependent and independent) were operationalized with reflective measures. In the operationalization of the measures, we adapted the items for (self-determined) autonomy, competence, and relatedness from La Guardia et al. (2000). Items for green purchase behavior were adapted from both Tang (2014) and Braga Junior et al. (2015), items for perceived customer effectiveness were adapted from Larson and Luczynski (2012) while items for perceived price were adapted from Lichtenstein et al. (1995).

Part two of the questionnaire centered on the demographic information of the respondents (gender, age, and education). In the spirits of King et al. (2014), DeVellis (2003) as well as Flynn and Pearcy (2001), we used scale generation and purification processes in purifying the scale items via the use of confirmatory factor analysis (CFA). Besides, we adopted the structural equation modeling (SEM) technique in assessing the various hypotheses stated earlier in the current study. Bagozzi and Yi (2012) and Byrne (2013) reckon that the SEM is a more preferred modeling approach because it enables researchers to control measurement error, provide information on the degree of fit of tested constructs as well as to control measurement error.

\subsection{Sample and Data Collection}

Data was collected from South Korean consumers. The respondents were selected purposively after their consent to partake in the study. In total, 470 respondents were sampled for the study. Prior to the administration of the questionnaire, a sufficient evaluation of the psychometric properties of the scale items was undertaken by testing for content and face validity via the use of $\mathrm{PhD}$ marketing students as well as University Professors (Bagozzi \& Yi, 1988). Out of the 470 respondents contacted, 459 were returned, from which six (6) had inconsistencies and had to be discarded. In effect, 453 valid questionnaires that showed acceptable adequacy were used for the intended analysis. Eventually, the final usable data represented a response rate of $96.4 \%$. 


\subsection{Profile of Respondents}

Outcomes of the distribution of the characteristics of the respondents revealed that they were adequately represented. As can be gleaned from Table 1, a profiling of the customers revealed that $54.7 \%$ were males while $45.3 \%$ were females. It emerged that the majority of the respondents $(49.0 \%)$ were between ages $26-$ 35 years, while $26.7 \%$ were between the ages $18-25$ years. The results further showed that $17.9 \%$ were between the ages 36-45 years, $4.6 \%$ were between ages $46-55$ years while $1.5 \%$ were at least 55 years old. Relative to education, a majority (46.6\%) indicated that their highest degree was a bachelors' degree, $34.9 \%$ indicated Masters' degree, and 13.2\% indicated high school while 5.3\% indicated a doctorate degree. Accordingly, it can be surmised that all the respondents had at least a high school education which qualifies them to partake in this research.

Table1- Profile of Respondents

\begin{tabular}{|c|c|c|c|c|c|c|c|}
\hline \multicolumn{2}{|c|}{ Classification } & \multirow{2}{*}{$\frac{\mathrm{N}}{248}$} & \multirow{2}{*}{$\begin{array}{c}\% \\
54.7\end{array}$} & \multicolumn{2}{|c|}{ Classification } & \multirow{2}{*}{$\begin{array}{l}\mathrm{N} \\
60\end{array}$} & \multirow{2}{*}{$\begin{array}{c}\% \\
13.2\end{array}$} \\
\hline Gender & Male & & & \multirow[t]{4}{*}{ Education } & $\begin{array}{l}\text { High } \\
\text { school }\end{array}$ & & \\
\hline & Female & 205 & 45.3 & & Bachelors & 211 & 46.6 \\
\hline \multirow[t]{5}{*}{ Age } & $\begin{array}{l}18-25 \\
\text { years }\end{array}$ & 121 & 26.7 & & Masters & 158 & 34.9 \\
\hline & $\begin{array}{l}26-35 \\
\text { years }\end{array}$ & 222 & 49.0 & & Doctorate & 24 & 5.3 \\
\hline & $\begin{array}{l}36-45 \\
\text { years }\end{array}$ & 81 & 17.9 & \multicolumn{2}{|l|}{ Total } & 453 & 100.0 \\
\hline & $\begin{array}{l}46-55 \\
\text { years }\end{array}$ & 21 & 4.6 & \multirow{2}{*}{\multicolumn{2}{|c|}{. }} & & \\
\hline & $\begin{array}{l}\text { Above } \\
55 \text { years }\end{array}$ & 8 & 1.8 & & & & \\
\hline
\end{tabular}

\subsection{Reliability and Validity Analysis of Variables}

Under the inspiration of Fornell and Larcker (1981), the reliability of the measurement scales was assessed by examining the internal consistencies and loadings on their respective constructs. The outcome revealed standard estimates that spanned 0.594 to 0.955 with corresponding internal consistency (Cronbach's Alpha) values ranging from 0.838 to 0.922 . We further employed confirmatory factor analysis (CFA) in testing for the measurement model. According to Hair et al. (2010), most model-fit indices must reach adequate thresholds to be qualified for model fitness. As is presented in Table 2, all the indicators for the CFA exceeded the benchmark values, indicating adequate fit to the data utilized. The CFA fitted well, in tandem with all the fit indices satisfying their corresponding threshold levels. Consequently, in line with Anderson and Gerbing (1988), $x^{2}=2.925, \mathrm{RMR}=.095, \mathrm{GFI}=.911, \mathrm{NFI}=.914, \mathrm{IFI}=.942$, TLI=.928, CFI=.941, and RMSEA=.065. Pegging the factor loadings at a significant level of 1 percent, convergent validity of the constructs was reinforced (Bagozzi \& Yi, 1988). Captured in Table 3 is the average variance extracted (AVE) that ranged from 0.755 to 0.833 . Moreover, by comparing the shared AVE values between pairs of constructs with their squared phi correlations, discriminant validity was established. In all the cases, AVE figures were higher than the share squared phi correlation linked with each pair of constructs. This signifies discriminant validity, indicative of the fact that the constructs are distinct from each other as reiterated by Fornell and Larcker (1981). Also, the correlation coefficients ranged from 0.046 to 0.488 . The results of the descriptive statistics, inter-construct correlations and the average variance extracted are presented in Table 3. 
Table 2- Measurement Model

\begin{tabular}{|c|c|c|c|c|c|c|c|}
\hline Item & Construct & $\begin{array}{c}\beta \\
\text { Estimate }\end{array}$ & Std. Err & t-value & (CR) & $\mathrm{P}$ & $\begin{array}{l}\text { Cronbach's } \\
\text { Alpha }(\alpha)\end{array}$ \\
\hline SDA2 & \multirow{4}{*}{$\begin{array}{l}\text { Self- } \\
\text { Determined } \\
\text { Autonomy }\end{array}$} & .955 & & & \multirow[t]{4}{*}{0.898} & & \multirow[t]{4}{*}{.922} \\
\hline SDA1 & & .925 & .028 & 34.704 & & $* * *$ & \\
\hline SDA3 & & .807 & .034 & 24.993 & & $* * *$ & \\
\hline SDA4 & & .598 & .045 & 14.821 & & $* * *$ & \\
\hline SDC1 & \multirow{4}{*}{$\begin{array}{c}\text { Self- } \\
\text { Determined } \\
\text { Competence }\end{array}$} & .819 & & & \multirow[t]{4}{*}{0.861} & & \multirow[t]{4}{*}{.853} \\
\hline SDC2 & & .819 & .054 & 18.366 & & **** & \\
\hline SDC3 & & .764 & .053 & 17.040 & & $* * *$ & \\
\hline SDC4 & & .712 & .069 & 15.660 & & $* * *$ & \\
\hline SDR3 & \multirow{4}{*}{$\begin{array}{c}\text { Self- } \\
\text { Determined } \\
\text { Relatedness }\end{array}$} & .880 & & & \multirow[t]{4}{*}{0.860} & & \multirow[t]{4}{*}{.838} \\
\hline SDR1 & & .816 & .055 & 17.389 & & **** & \\
\hline SDR2 & & .788 & .065 & 16.305 & & $* * *$ & \\
\hline SDR4 & & .613 & .058 & 13.130 & & $* * *$ & \\
\hline GBP3 & \multirow{4}{*}{$\begin{array}{c}\text { Green } \\
\text { Purchase } \\
\text { Behavior }\end{array}$} & .803 & & & \multirow[t]{4}{*}{0.880} & & \multirow[t]{4}{*}{.858} \\
\hline GBP2 & & .848 & .063 & 17.254 & & $* * *$ & \\
\hline GBP4 & & .850 & .074 & 15.272 & & $* * *$ & \\
\hline GBP1 & & .710 & .058 & 15.082 & & $* * *$ & \\
\hline PCE1 & \multirow{4}{*}{$\begin{array}{c}\text { Perceived } \\
\text { Customer } \\
\text { Effectiveness }\end{array}$} & .745 & & & \multirow[t]{4}{*}{0.839} & & \multirow[t]{4}{*}{.847} \\
\hline PCE2 & & .798 & .072 & 15.969 & & $* * *$ & \\
\hline PCE4 & & .594 & .059 & 13.318 & & $* * *$ & \\
\hline PCE3 & & .858 & .068 & 16.640 & & $* * *$ & \\
\hline
\end{tabular}

(Model fit: ${ }^{\prime 2}=2.925, \mathrm{RMR}=.095$, GFI $=.911, \mathrm{NFI}=.914$, IFI $=.942, \mathrm{TLI}=.928, \mathrm{CFI}=.941$, RMSEA $=.065$ )

Figure 2. Final Measurement Model

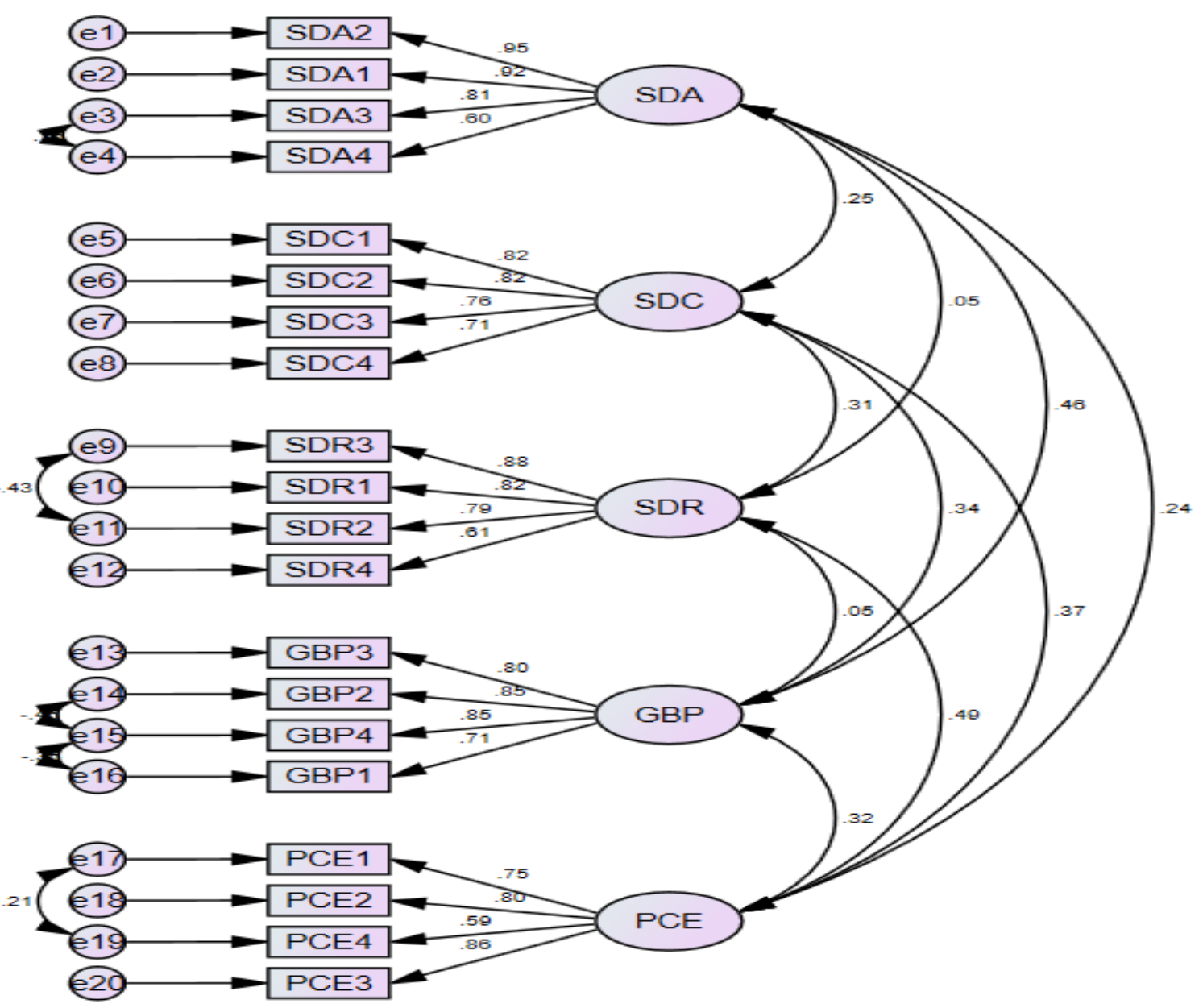


Table 3-Descriptives Statistics and Correlations

\begin{tabular}{|l|l|l|c|c|c|c|c|}
\hline & Mean & St. d. & $\mathbf{1}$ & $\mathbf{2}$ & $\mathbf{3}$ & $\mathbf{4}$ & $\mathbf{5}$ \\
\hline SDA (1) & 3.5729 & 1.05580 & $\mathbf{0 . 8 3 3}$ & & & & \\
\hline SDC(2) & 3.0842 & .82148 & $0.254^{* * *}$ & $\mathbf{0 . 7 8 0}$ & & & \\
\hline SDR (3) & 2.5682 & .97941 & 0.046 & $0.313^{* * *}$ & $\mathbf{0 . 7 8 0}$ & & \\
\hline GBP(4) & 3.4358 & .75822 & $0.461^{* * *}$ & $0.342^{* * *}$ & 0.055 & $\mathbf{0 . 8 0 5}$ & \\
\hline PCE(5) & 2.7758 & .83378 & $0.236^{* * *}$ & $0.373^{* * *}$ & $0.488^{* * *}$ & $0.321^{* * *}$ & $\mathbf{0 . 7 5 5}$ \\
\hline
\end{tabular}

Average variance extracted (AVE) are on the diagonal; squared correlations are off-diagonal.

Note: Significance of Correlations: $\dagger p<0.100,{ }^{*} p<0.050,{ }^{* *} p<0.010,{ }^{* * *} p<0.001$

\subsection{Model Fit and Hypothesis Test}

As depicted in Table 4, the parameter estimates represent the final results which adduce a better authentication to the findings of the study in tandem with the hypotheses proffered. The model fit indices for the structural model portrayed confirmation of a good model fit $\left(x^{2}=2.925, \mathrm{RMR}=.095, \mathrm{GFI}=.911, \mathrm{NFI}=.914\right.$, $\mathrm{IFI}=.942$, TLI=.928, CFI=.941, RMSEA=.065). Hypothesis one (H1) states that there is a positive and significant effect of autonomy on perceived customer effectiveness. Relative to this hypothesis, the structural equations modeling results indicated that there is indeed a positive and significant relationship between autonomy and perceived customer effectiveness $(\beta=.175, \mathrm{t}=4.554, \mathrm{p}<0.05)$. The second hypothesis $(\mathrm{H} 2)$ states that there is a positive and significant effect of competence on perceived customer effectiveness. Concerning this hypothesis, the structural equations modeling results indicated a positive and significant relationship between competence and perceived customer effectiveness $(\beta=.218, \mathrm{t}=5.317, \mathrm{p}<$ 0.05). Hypothesis three (H3) states that there is a positive and significant effect of relatedness on perceived customer effectiveness.

The SEM outcome shows a positive and significant effect of relatedness on perceived customer effectiveness $(\beta=.454, \mathrm{t}=11.522, \mathrm{p}<0.05)$. Similarly, the fourth hypothesis (There is a positive and significant effect of autonomy on green purchase behavior) received empirical support $(\beta=.281, t=6.236, p$ $<0.05)$. The SEM results also adduced empirical support for the fifth hypothesis (H5) which states that there is a positive and significant effect of competence on green purchase behavior with $(\beta=.220, t=5.002, p<$ $0.05)$. Furthermore, hypothesis six states that there is a positive and significant effect of relatedness on green purchase behavior. The SEM results showed a negative but statistically significant effect of relatedness on green purchase behavior $(\beta=-.161, \mathrm{t}=-3.540, \mathrm{p}<0.05)$. Hypothesis seven (There is a positive and significant relationship between perceived consumer effectiveness and green purchase behavior) received statistical support $(\beta=223, t=4.702, p<0.05)$. Finally, hypothesis eight $(\mathrm{H} 8)$ states that perceived price moderates the relationship between perceived customer effectiveness and green purchase behavior. Concerning this hypothesis, the structural equations modeling results showed that price moderates the relationship between perceived customer effectiveness and green purchase behavior as both the direct effects and the interaction effect were both significant. However, because the $\beta$ estimate for the interaction was negative it can be argued that price dampens the positive relationship between perceived customer effectiveness and green purchase behavior. In effect, the higher the price of the green product, the lesser the effect of the customer perceived effectiveness on green purchase behavior (see Table 5 and Figure 3 respectively). Consequently, the entire hypotheses (except for H6) were supported.

Table 4. Structural Model and Assessment Results

\begin{tabular}{|l|c|c|c|c|c|}
\hline \multicolumn{1}{|c|}{ Structural Relationships } & $\begin{array}{c}\beta \\
\text { Estimate }\end{array}$ & $\begin{array}{l}\text { Std. } \\
\text { Err }\end{array}$ & t-value & P & Decision \\
\hline $\begin{array}{l}\text { (H1) Perceived Customer Effectiveness<--- Self-Determined } \\
\text { Autonomy }\end{array}$ & .175 & .030 & 4.554 & $* * *$ & Supported \\
\hline $\begin{array}{l}\text { (H2) Perceived Customer Effectiveness <--- Self-Determined } \\
\text { Competence }\end{array}$ & .218 & .042 & 5.317 & $* * *$ & Supported \\
\hline $\begin{array}{l}\text { (H3) Perceived Customer Effectiveness <--- Self-Determined } \\
\text { Relatedness }\end{array}$ & .454 & .034 & 11.522 & $* * *$ & Supported \\
\hline (H4) Green Purchase Behavior <--- Self-Determined Autonomy & .281 & .032 & 6.236 & $* * *$ & Supported \\
\hline (H5) Green Purchase Behavior <--- Self-Determined Competence & .220 & .040 & 5.002 & $* * *$ & Supported \\
\hline (H6) Green Purchase Behavior <--- Self-Determined Relatedness & -.161 & .035 & -3.540 & $* * *$ & $\begin{array}{l}\text { Not } \\
\text { Supported }\end{array}$ \\
\hline $\begin{array}{l}\text { (H7) Green Purchase Behavior <--- PCE } \\
\text { (Model fit: } x^{2}=2.925, \text { RMR=.095, GFI=.911, NFI=.914, IFI=.942, TLI=.928, CFI=.941, RMSEA } \\
\text { =.065) }\end{array}$ & .223 & .043 & 4.702 & $* * *$ & Supported \\
\hline
\end{tabular}


Table 5. Summary of Moderation Test

\begin{tabular}{|c|c|c|c|c|c|}
\hline Moderating effects & $\begin{array}{c}\beta \\
\text { Estimate }\end{array}$ & $\begin{array}{c}\text { Std. } \\
\text { Err }\end{array}$ & t-value & P & Decision \\
\hline $\begin{array}{c}\text { Green Purchase Behavior <--- Price X Perceived Customer } \\
\text { Effectiveness }\end{array}$ & -.107 & .025 & -2.767 & .006 & $\begin{array}{c}\text { Supported } \\
\text { as both } \\
\text { direct and } \\
\text { moderated } \\
\text { paths are } \\
\text { significant }\end{array}$ \\
\hline Green Purchase Behavior <--- Price & .168 & .039 & 3.704 & $* * *$ \\
\hline
\end{tabular}

Figure 3. Moderation Analysis

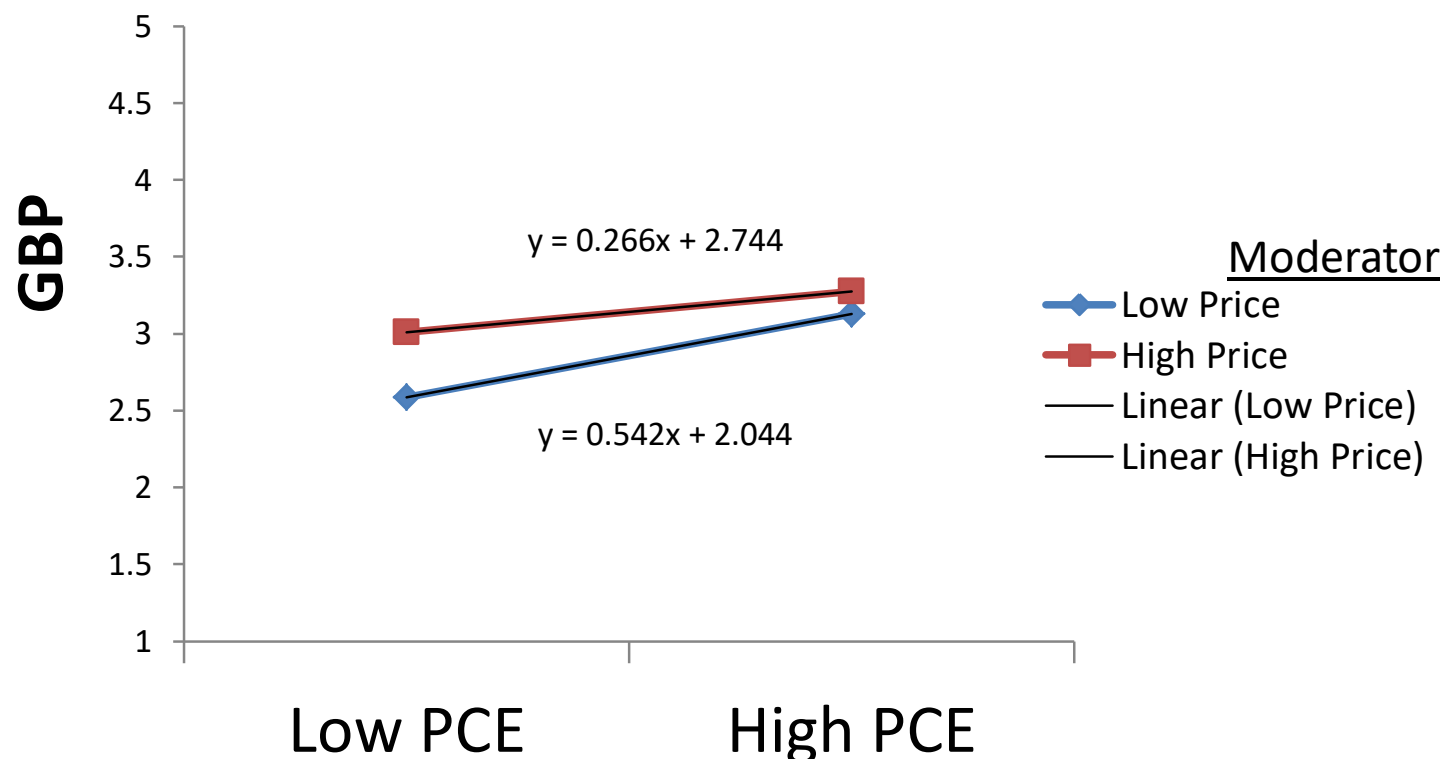

Figure 4. Structural Model

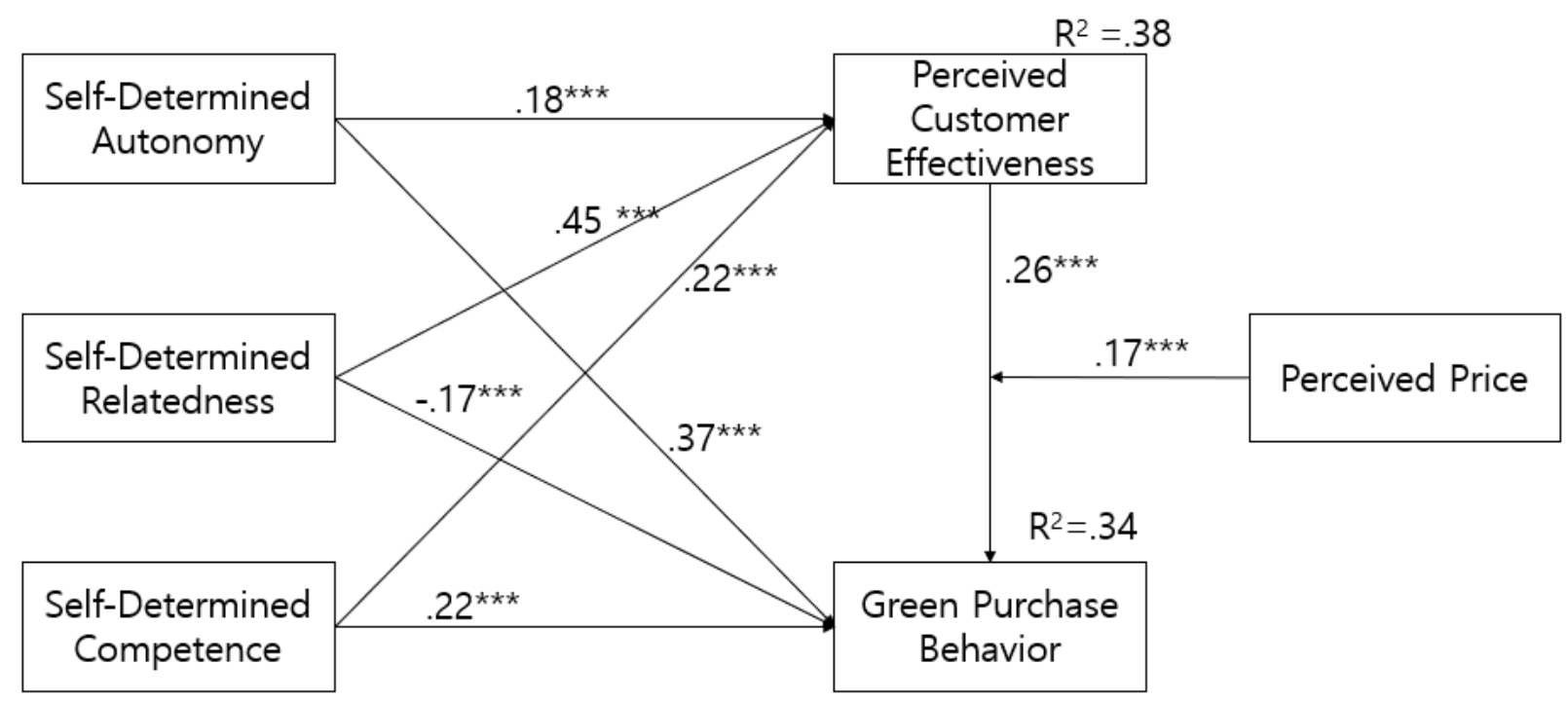

\subsection{Summary And Conclusions}

\subsection{Summary of Findings}

The current study sheds light on how consumers' self-determined needs (autonomy, competence, and relatedness) influence their perceived customer effectiveness and green purchase behavior. The study further examines the moderating role of price in the same relationship. The research assessed these relationships anchored on the self-determination theory. Generally, the study found autonomy, competence, and 
relatedness as germane to perceived customer effectiveness. This outcome is in tandem with extant research (Thyroff et al., 2013; Deci \& Ryan, 2000; Ryan \& Deci, 2000) which maintain that in the ambit of the proenvironmental literature, perceived customer effectiveness is a function of how consumers trust their ability and locus to influence and contribute positively to the environment which is premised on their needs to satisfying their basic physical and psychological needs (autonomy, competence, and relatedness). Thus in consonance with previous studies, this research reinforces the position that customer's self-determined needs of autonomy, competence and relatedness engenders perceived customer effectiveness.

Additionally, the results adduced statistical backing for a positive and significant relationship between both autonomy and competence and green purchase behavior. These outcomes resonate with previous research (deCharms, 1968; Harter, 1978; White, 1963; Baumeister \& Leary, 1995; Deci, 1985; deCharms, 1968) which have all reckoned that all the three self-determined needs (basic psychological needs) are premised on the notion of the locus of causality, being the origin of one's actions, rather than being pulled by external forces (and therefore consumers who are intrinsically motivated through satisfying their needs for autonomy, competence and relatedness will eventually be predisposed towards engaging in green purchases. This research thus, in tandem with prior research corroborates the notion that consumers' need for autonomy and competence is a sine qua non to their green purchase behavior. The results, however, could not adduce statistical support for a positive relationship between relatedness and green purchase behavior, even though the relationship was statistically significant. Accordingly, though this outcome is unexpected, it can be argued than the significant nature of the relationship lends some support to the prior research discussed above, but further research may validate or disapprove the negative relationship between same. This result, however, lends some support to scholars who have argued that the need for relatedness is sometimes characterized as being less immediately essential for some outcomes than the needs for autonomy or competence (Broeck \& Rosen, 2016; Deci \& Ryan, 2000).

Furthermore, the results found support for a positive and significant relationship between perceived customer effectiveness and green purchase behavior. This outcome lends credence to Vermeir and Verbeke (2008) who opine that in the domain of green consumption, perceived customer effectiveness is a crucial predictor of green behavioral intentions. This outcome is also consistent with Berger and Corbin (1992) who aver that perceived consumer effectiveness has a positive effect on environmentally friendly behavior. In effect, this research, in line with extant research emphasizes the argument that perceived customer effectiveness is germane to green purchase behavior. One noteworthy outcome of the current research is the role played by perceived price in moderating the relationship between perceived customer effectiveness and green purchase behavior. In effect, this research contributes to extant knowledge to the extent that it has uncovered that the nexus between perceived customer effectiveness and green purchase behavior is largely influenced by the perceived price of the green product. Specifically, it is crucial to observe that the standard estimate of the interaction was negative (but significant). This implies that price dampens the positive relationship between PCE and GBP. In effect, even at high levels of perceived customer effectiveness, consumers may not necessarily buy green products if the prices of green products are high and vice versa. This outcome lends empirical support to Gummesson (2008) who notes that price and cost savings are closely tied to any purchasing process and even among environmentally conscious consumers, price is a dominant factor that can make a customer avoid buying a green product. This outcome further underscores Pedro and Lemke's (2013) position that if a green product is highly expensive, few consumers pay attention to such products and may be discouraged from patronizing same. Consequently, the current study contributes to extant knowledge and debates by reinforcing the argument that perceived price moderates the relationship between perceived customer effectiveness and green purchase behavior.

Overall, the current study progresses knowledge and adduces practical and empirical illuminations to the question that has remained mainly unaddressed in the extant environmental sustainability literature: "What is the role of customers' self-determination/self-determined needs and perceived customer effectiveness in engendering green purchase behavior?". This research reveals that consumers' self-determined needs (need for autonomy, competence, and relatedness) influence their perceived customer effectiveness. The study further finds that autonomy and competence (but not relatedness) positively and significantly influences green purchase behavior (though relatedness significantly influences green purchase behavior). Further, the 
research finds that perceived customer effectiveness is essential in predicting green purchase behavior. Finally, this study reveals that price moderates the relationship between perceived customer effectiveness and green purchase behavior. In order words, price dampens the positive relationship between perceived customer effectiveness and green purchase behavior.

\subsection{Theoretical Implication}

The current research progresses theory by extending the self-determination theory on a flourishing phenomenon-green purchase behavior. The extant literature on green purchase behavior and perceived customer effectiveness shows a lacuna and paucity of research anchored on the self-determination theory. In effect, the current study modestly contributes to that effect, by providing empirical support form a consumer self-determined needs and perceived customer effectiveness perspectives for this essentially acknowledged theory (Ryan \& Deci, 2000; Harter, 1978; White, 1963; Deci, 1985; deCharms, 1968; Deci \& Ryan, 2000; Vlachopoulos \& Michailidou, 2006; Ryan and La Guardia (2000) with a conceptual model that demonstrates rigor, robustness and good explanatory power. Secondly, the literature on green purchase behavior shows limited empirical studies that merge and evaluates the relationships among the constructs adopted in the current study, specifically on the dimensions of self-determined needs, perceived customer effectiveness, and perceived price. Prior research either examined the interconnections among these variables in isolation or in conjunction with different constructs (Dagher and Itani (2012; Vermillion \& Peart, 2010; Abdul Wahid et al., 2011), provoking the need for additional empirical evaluations, validation and theory building. Besides, the current study contributes to knowledge by presenting outcomes that assess multiple nexuses among the constructs utilized, as well as using data from consumers from a South Korean context.

\subsection{Managerial Implications}

Getting enormous insights into how consumers' self-determined needs influence their green purchase behavior provides new guidelines in managing issues such as green purchase behavior. Significant empirical findings in this research can be observed from these main perspectives: that autonomy, competence, and relatedness are instrumental in predicting perceived customer effectiveness. That autonomy and competence (but not relatedness) are positive and significant antecedents of green purchase behavior; that perceived customer effectiveness is germane to green purchase behavior and that perceived price moderates the relationship between perceived customer effectiveness and green purchase behavior. Accordingly, to encourage and enhance green purchase behavior, and to boost perceived customer effectiveness, adverts and communication strategies that seek to enhance consumers' feelings of autonomy, competence and relatedness should be deployed. Similarly, to enhance green purchase behavior, marketers and strategists of green products must ensure that prices are not too high or should be able to effectively communicate the pricing strategies in ways that attenuate any resistance to their products. Also, marketers must put in a concerted effort to communicate the advantages of consuming green and environmentally sustainable products as that will also go a long way in influencing consumers' purchase behaviors.

\subsection{Limitations and Future Research}

Consistent with any empirical inquiry, the current study comes along with some limitations providing fresh avenues for future research. In the first instance, this research is limited to South Korean consumers only. Consequently, the findings are only within this remit, implying that practitioners and scholars should exercise high levels of caution in attempting to universally generalize it with other contexts. Similarly, the various hypotheses proffered in this study were tested using respondents in a single country, is crosssectional and hence, may not yield static effects in other contexts. Moreover, due to disparities in contexts, subsequent research is needed to validate and substantiate the construct relationships and outcomes from this research. Furthermore, the effects tested were relationships and not causalities. The concepts examined in the current study are also relevant across different economic contexts. Accordingly, these outcomes open up fresh debates on the concept under investigation, particularly, the incongruities that may emerge between perceived customer effectiveness and green purchase behavior as well as the moderating role played by perceived price. Additional research that adopts different antecedents of green purchase behavior is highly encouraged. 


\section{Conclusion}

The predominant aim of this research was to empirically test the effect of customers' self-determined needs on perceived customer effectiveness and green purchase behavior while assessing the moderating role of perceived price. The results of the study revealed that autonomy, competence, and relatedness positively and significantly affect perceived customer effectiveness. Additionally, autonomy and competence positively and significantly influence green purchase behavior. The study further finds that relatedness is negative but significantly related to green purchase behavior. Moreover, the study reveals that perceived customer effectiveness is positive and significantly related to green purchase behavior. Similarly, the study finds support for the moderating effect of price on the relationship between perceived customer effectiveness and green purchase behavior.

\section{References}

[1] Abeliotis, K., Koniari, C., \& Sardianou, E. (2010). The Profile of the Green Consumer in Greece. International Journal of Consumer Studies, 34(2), 153-160

[2] Ajzen, I., \& Madden, T. J. (1986). Prediction of goal-directed behavior: Attitudes, intentions, and perceived behavioral control. Journal of experimental social psychology, 22(5), 453-474.

[3] Ajzen, I. (1985). From intentions to actions: A theory of planned behavior. In Action control (pp. 1139). Springer, Berlin, Heidelberg.

[4] Bagozzi, R. P., \& Yi, Y. (1988). On the evaluation of structural equation models. Journal of the academy of marketing science, 16(1), 74-94.

[5] Bagozzi, R. P., \& Yi, Y. (2012). Specification, evaluation, and interpretation of structural equation models. Journal of the academy of marketing science, 40(1), 8-34.

[6] Barbarossa, C., \& De Pelsmacker, P. (2016). Positive and Negative Antecedents of Purchasing Ecofriendly Products: A Comparison Between Green and Non-green Consumers. Journal of Business Ethics, 134(2), 229-247.

[7] Baumeister, R. F., \& Leary, M. R. (1995). The need to belong: desire for interpersonal attachments as a fundamental human motivation. Psychological bulletin, 117(3), 497.

[8] Berger, I. E., \& Corbin, R. M. (1992). Perceived consumer effectiveness and faith in others as moderators of environmentally responsible behaviors. Journal of Public Policy \& Marketing, 11(2), 79-89.

[9] Biswas, A., \& Roy, M. (2015). Green products: an exploratory study on the consumer behaviour in emerging economies of the East. Journal of Cleaner Production, 87, 463-468.

[10] Blend, J. R., \& Van Ravenswaay, E. O. (1999). Measuring consumer demand for Eco labeled apples. American Journal of Agricultural Economics, 81(5), 1072-1077.

[11] Byrne, B. M. (2013). Structural equation modeling with LISREL, PRELIS, and SIMPLIS: Basic concepts, applications, and programming. Psychology Press.

[12] Cho, Y. N., Thyroff, A., Rapert, M. I., Park, S. Y., \& Lee, H. J. (2013). To be or not to be green: Exploring individualism and collectivism as antecedents of environmental behavior. Journal of Business Research, 66(8), 1052-1059.

[13] Dagher, G., \& Itani, O. (2012). The influence of environmental attitude, environmental concern and social influence on green purchasing behavior. Review of Business Research, 12(2), 104-111.

[14] deCharms, R. (1968) Personal Causation. New York: Academic Press.

[15] Deci, E. L., \& Ryan, R. M. (1985). The general causality orientations scale: Self-determination in personality. Journal of research in personality, 19(2), 109-134.

[16] Deci, E. L., \& Ryan, R. M. (2000). The" what" and" why" of goal pursuits: Human needs and the self-determination of behavior. Psychological inquiry, 11(4), 227-268.

[17] Deci, E. L., Koestner, R., \& Ryan, R. M. (1999). A meta-analytic review of experiments examining the effects of extrinsic rewards on intrinsic motivation. Psychological bulletin, 125(6), 627.

[18] DeVellis Robert, F. (2003). Scale development: theory and applications.

[19] D'Souza, C., Taghian, M., \& Lamb, P. (2006). An empirical study on the influence of environmental labels on consumers. Corporate communications: an international journal, 11(2), 162-173.

[20] East, R. (1997). Consumer behaviour: Advances and applications in marketing. Prentice Hall. 
[21] Ellen, P. S., Wiener, J. L., \& Cobb-Walgren, C. (1991). The role of perceived consumer effectiveness in motivating environmentally conscious behaviors. Journal of public policy \& marketing, 10(2), 102-117.

[22] Flynn, L. R., \& Pearcy, D. (2001). Four subtle sins in scale development: some suggestions for strengthening the current paradigm. International Journal of Market Research, 43(4), 1-14.

[23] Fornell, C., \& Larcker, D. F. (1981). Structural equation models with unobservable variables and measurement error: Algebra and statistics.

[24] Gummesson, E. (2008). Quality, service-dominant logic and many-to-many marketing. The TQM Journal, 20(2), 143-153.

[25] Hair, J. F., Anderson, R. E., Babin, B. J., \& Black, W. C. (2010). Multivariate data analysis: A global perspective, 7.

[26] Harter, S. (1978). Effectance motivation reconsidered. Toward a developmental model. Human development, 21(1), 34-64.

[27] Henion, K. E., \& Wilson, W. H. (1976). The ecologically concerned consumer and locus of control. Ecological marketing, 11, 131-144.

[28] Hsu, C. L., \& Lin, J. C. C. (2015). What drives purchase intention for paid mobile apps?-An expectation confirmation model with perceived value. Electronic Commerce Research and Applications, 14(1), 46-57.

[29] Junior, S. S. B., da Silva, D., Gabriel, M. L. D., \& de Oliveira Braga, W. R. (2015). The effects of environmental concern on purchase of green products in retail. Procedia-Social and Behavioral Sciences, 170, 99-108.

[30] Kim, Y., \& Choi, S. M. (2005). Antecedents of green purchase behavior: An examination of collectivism, environmental concern, and PCE. ACR North American Advances.

[31] King, R. A., Racherla, P., \& Bush, V. D. (2014). What we know and don't know about online wordof-mouth: A review and synthesis of the literature. Journal of interactive marketing, 28(3), 167-183.

[32] Kotler, P. (2011). Reinventing marketing to manage the environmental imperative. Journal of Marketing, 75(4), 132-135.

[33] Kumar, P., \& Polonsky, M. J. (2017). An Analysis of the Green Consumer Domain within Sustainability Research: 1975 to 2014. Australasian Marketing Journal, 25(2), 85-96.

[34] La Guardia, J. G., Ryan, R. M., Couchman, C. E., \& Deci, E. L. (2000). Within-person variation in security of attachment: a self-determination theory perspective on attachment, need fulfillment, and well-being. Journal of personality and social psychology, 79(3), 367.

[35] Laroche, M., Bergeron, J., \& Barbaro-Forleo, G. (2001). Targeting consumers who are willing to pay more for environmentally friendly products. Journal of consumer marketing, 18(6), 503-520.

[36] Leonidou, C. N., \& Leonidou, L. C. (2011). Research into Environmental Marketing/Management: A Bibliographic Analysis. European Journal of Marketing, 45(1-2), 68-103

[37] Leonidou, L. C., Leonidou, C. N., \& Kvasova, O. (2010). Antecedents and Outcomes of Consumer Environmentally Friendly Attitudes and Behaviour. Journal of Marketing Management, 26(13/14), 1319-1344

[38] Liobikienè, G., \& Bernatonienè, J. (2017). Why determinants of Green Purchase Cannot be Treated Equally? The Case of Green Cosmetics: Literature Review. Journal of Cleaner Production, 162, 109120.

[39] Manget, J., Roche, C., \& Munnich, F. (2009). Capturing the green advantage for consumer companies. The Boston Consulting Group, 13.

[40] McDonagh, P., \& Prothero, A. (2014). Sustainability Marketing Research: Past, Present and Future. Journal of Marketing Management, 30(11-12), 1186-1219

[41] Möller, K. (2006). Role of competences in creating customer value: A value-creation logic approach. Industrial marketing management, 35(8), 913-924.

[42] Mostafa, M. M. (2007). Gender differences in Egyptian consumers' green purchase behaviour: the effects of environmental knowledge, concern and attitude. International Journal of Consumer Studies, 31(3), 220-229.

[43] Nguyen, T. N., Lobo, A., \& Greenland, S. (2016). Pro-environmental Purchase Behaviour: The Role of Consumers' Biospheric Values. Journal of Retailing and Consumer Services, 33, 98-108. 
[44] Olson, E. L. (2013). It's Not Easy Being Green: The Effects of Attribute Tradeoffs on Green Product Preference and Choice. Journal of the Academy of Marketing Science, 41(2), 171-184.

[45] Peattie, K. (2001). Towards sustainability: the third age of green marketing. The Marketing Review, 2(2), 129-146.

[46] Pedro Pereira Luzio, J., \& Lemke, F. (2013). Exploring green consumers' product demands and consumption processes: The case of Portuguese green consumers. European Business Review, 25(3), 281-300.

[47] Polonsky, M. J. (2011). Transformative Green Marketing: Impediments and Opportunities. Journal of Business Research, 64(12), 1311-1319

[48] Prothero, A., Dobscha, S., Freund, J., Kilbourne, W., Luchs, M. G., Ozanne, L. K., \& Th gersen, J. (2011). Sustainable Consumption: Opportunities for Consumer Research and Public Policy. Journal of Public Policy \& Marketing, 30(1), 31-38

[49] Rahbar, E., \& Abdul Wahid, N. (2011). Investigation of green marketing tools' effect on consumers' purchase behavior. Business strategy series, 12(2), 73-83.

[50] Rehman, Z., \& Dost, M. K. (2013, June). Conceptualizing green purchase intention in Emerging markets: An empirical analysis on Pakistan. In The 2013 WEI International Academic Conference Proceedings (pp. 99-120).

[51] Romani, S., Grappi, S., \& Bagozzi, R. P. (2016). Corporate Socially Responsible Initiatives and Their Effects on Consumption of Green Products. Journal of Business Ethics, 135(2), 253-264.

[52] Ryan, R. M., \& Deci, E. L. (2000). Intrinsic and extrinsic motivations: Classic definitions and new directions. Contemporary educational psychology, 25(1), 54-67.

[53] Ryan, R. M., \& La Guardia, J. G. (2000). What is being optimized? Self-determination theory and basic psychological needs.

[54] Shahnaei, S. (2012). The impact of individual differences on green purchasing of Malaysian consumers. International Journal of Business and Social Science, 3(16).

[55] Sharma, V. K., Chandna, P., \& Bhardwaj, A. (2017). Green supply chain management related performance indicators in agro industry: A review. Journal of Cleaner Production, 141, 1194-1208.

[56] Steg, L., Bolderdijk, J. W., Keizer, K., \& Perlaviciute, G. (2014). An Integrated Framework for Encouraging Pro-environmental Behaviour: The Role of Values, Situational Factors and Goals. Journal of Environmental Psychology, 38, 104-115.

[57] Tang, S. M. (2014). Factors that influence green purchase behaviour of Malaysian consumers (Doctoral dissertation, UTAR)

[58] Thompson, J. B. (1981). Hermeneutics and the human sciences: essays on language, action and interpretation.

[59] Tilikidou, I., \& Delistavrou, A. (2014). Pro-Environmental Purchasing Behaviour During the Economic Crisis. Marketing Intelligence \& Planning, 32(2), 160-173

[60] UNEP. (2015). UNEP 2014 Annual Report. Retrieved 16 April 2016, from United Nations Environment Programme http://www.unep.org/annualreport/2015/en/index.html

[61] UNEP. (2016). UNEP Frontiers 2016 Report: Emerging Issues of Environmental Concern. Nairobi, Kenya: United Nations Environment Programme

[62] Vallerand, R. J., \& Ratelle, C. F. (2002). Intrinsic and extrinsic motivation: A hierarchical model. Handbook of self-determination research, 128, 37-63.

[63] Vermeir, I., \& Verbeke, W. (2006). Sustainable food consumption: Exploring the consumer "attitude-behavioral intention" gap. Journal of Agricultural and Environmental ethics, 19(2), 169194.

[64] Vermillion, L. J., \& Peart, J. (2010). Green Marketing: Making sense of the situation', paper presented to Allied Academies International Conference. Proceedings of the Academy of Marketing Studies, New Orleans, LA, April, 1.

[65] Vlachopoulos, S. P., \& Michailidou, S. (2006). Development and initial validation of a measure of autonomy, competence, and relatedness in exercise: The Basic Psychological Needs in Exercise Scale. Measurement in physical education and exercise science, 10(3), 179-201.

[66] Wahid, N. A., Rahbar, E., \& Shyan, T. S. (2011). Factors influencing the green purchase behavior of Penang environmental volunteers. International Business Management, 5(1), 38-49. 
[67] Wesley, S. C., Lee, M. Y., \& Kim, E. Y. (2012). The role of perceived consumer effectiveness and motivational attitude on socially responsible purchasing behavior in South Korea. Journal of Global Marketing, 25(1), 29-44.

[68] White, R. W. (1963). Ego and reality in psychoanalytic theory. Psychological issues.

[69] Williams, G. C., Minicucci, D. S., Kouides, R. W., Levesque, C. S., Chirkov, V. I., Ryan, R. M., \& Deci, E. L. (2002). Self-determination, smoking, diet and health. Health education research, 17(5), $512-521$. 